Submission to Academia Letters

\title{
The Contemporary Heritage as an Identity of the Nation's Local Wisdom; A Study of Dubai's Al Seef Khor
}

Kurniawan Arif Maspul, International Open University

Dubai is a coveted city for anyone in the world to visit, that not a few visitors from 198 countries in the world must stop by Dubai to see everything set up super taller and massive, super luxurious, and super best of all that the world has (Krane, 2009; Reisz, 2020). As people can see from the Burj Khalifa, the tallest building globally, the largest artificial island globally, and the longest artificial canal in the world. It will not stop; Dubai's development is always a renewal in various sectors (Davidson, 2007; Marzooqi et al., 2017). Not only that, but Dubai also has creativity in developing global-scale events through expos and other events that make other countries delegate their countries to participate in following the trend of progress made by Dubai (Belting, 2009; Noori et al., 2020; Sindelar, 2016). This is done by Dubai to boost tourism as a core economy in the United Arab Emirates, which is the vision and mission of its leader, Mohammed bin Rashid al Maktoum (Al Maktoum, 2001; Alhosani \& Zaidan, 2014; Sharpley, 2008). This study is a qualitative analysis of wherewith the United Arab Emirates government works to maintain the sustainability of culture and heritage as local wisdom integrity.

The number of visitors who never stop wanting to see something great and become proud of the progress in Dubai society's rich architecture and modernity (Al-Sayegh, 1998; Govers, 2012). In this case, it will add a new identity for Dubai as a leading global tourism city (Elsheshtawy, 2004; Stephenson, 2014). On the other hand, it causes the loss of the identity of a historical community as an Arab with an unpretentious personality, which is the local wisdom possessed

Academia Letters preprint.

(O2021 by the author - Open Access - Distributed under CC BY 4.0 
by the people of Dubai that must be maintained (Mungmachon, 2012; Rahman et al., 2018). Reflecting on the developed cities in the world where the progress of a city will not be separated from the preservation of the city's heritage, it has a history as the identity of the local wisdom of its citizens (Dahliani, 2010; Yas et al., 2020). Likewise, Dubai is developing its old city area, even developing new areas to continue to strengthen Dubai's historical and cultural heritage, where the Khor Creek area focuses on cultural heritage(Boussaa, 2014; Ryan et al., 2012).

Khor creek is the history of Dubai's culture when it first existed, where people as traders in history came back and forth from the Persian Gulf, making Dubai a trading hub from the early 18th century (Boussaa, 2003; Carter, 2015). It is interesting to observe here because we see that the cross-culture that has been formed over the centuries has made the identity of the citizens of Dubai unique as one of the advanced trading nations (Gemenetzi, n.d.; Zaidan, 2016). World Heritage Sites are designated by the United Nations Educational, Scientific and Cultural Organization (UNESCO) to identify cultural and historical significance places. Delimited as a protected zone, the UNESCO heritage site in the UAE is a major draw for history buffs and regular tourists looking to glimpse the country's glorious past, which focuses on areas in the United Arab Emirates (Cuerrier et al., 2015; Ricca, 2018). One area that is the main focus is Khor Dubai, one of the tentative UNESCO heritage sites in the UAE (Farooq et al., n.d.; Ryan et al., 2012). It is shown by the maintenance of the Al Khor area, which is a spot for Dubai's cultural and historical area. The natural seawater inlet in the Arabian Gulf divides Deira and Bur Dubai and stretches for 14 km (Elessawy, 2017; Kaiser \& AG, 2007). Also known as Dubai Creek, this site was a focal point of Dubai's development as a trading port with the first recorded reference since 1587 (Alawadi, 2017; Ezzeddine \& Kashwani, 2019).

Observing the history of Dubai, which is unique in its culture, here as a form of local wisdom in Dubai, an area that is a rich history of Dubai itself was developed; Al Seef Khor. Set on the edge of Bur Dubai on Dubai Creek, property developer Meraas' new destination is filled with retail and restaurants. With ancient Dubai architecture that brings local wisdom from Dubai's history and culture, a vast amount of Dubai Emirati culture itself. Meraas became the developer of Al Seef; they aspired to bring together contemporary elements of

Academia Letters preprint.

(O2021 by the author - Open Access - Distributed under CC BY 4.0 
today's Dubai and combine them with historical nostalgia and influences from the mid-late 1900s. With Dubai's always buzzing and renewable attractions, Al Seef draws on elements of contemporary life in Dubai in 2018, but at the same time, reflects and pays homage to the city that once existed. Life in Dubai is centred around the River in the early 20th century. Location It still separates Dubai's two central districts, Deira and Bur Dubai, and is the emirate's prominent trading centre. The Creek hosts the only harbour on the city's edge and is critical in developing Dubai's pearl diving industry, which helps the economy thrive (Henderson, 2006; Lowry \& McCann, 2011).

It's $1.8 \mathrm{~km}$ long trail is divided into two very different areas. A modern site is characterised by contemporary heritage modelled on Old Dubai, with narrow corridors, market stall vendors, and buildings made in an old-style finish. There's intentional rust on the roadside pillar box or power outlet, and the air conditioning unit, while modern and efficient, is made to look as if it's been around since the 60s. The developer is set to place a modern facade in one of the city's more historical and traditional areas, with a large development offering dining, retail, recreation and tourism, among others (Assi, 2020; Carter, 2015; Maspul, 2021).

\section{Conclusion}

Progress for the country, known as a developed nation globally, without letting go of the noble character symbolised through an artificial place but closely related to the local historical period at the beginning of Dubai's development. People do not see the period in the future how Dubai will lead the world in modernising architecture with all its super-reviving inventions and welcome the world to visit. However, Dubai still has its local wisdom through the cultural identity that emerged in this $\mathrm{Al}$ Seef area. With a vast area built as a point to focus on the local wisdom, both in the form of old buildings to the details of the architecture, it has convenient and beneficial value in elevating the identity of a progressive nation.

Preserving this culture will strengthen the sustainability of the social part as a nation with a progressive culture to strengthen the nation's economy and the preservation of cultural heritage. By uniting traditional and modern design elements, the destination highlights the role the Creek has performed and continues to explore in the evolution of Dubai. It will reinforce the city's position

Academia Letters preprint.

(O2021 by the author - Open Access - Distributed under CC BY 4.0 
as a leading international tourism destination by enhancing the unique experience for visitors and designing new economic opportunities for local businesses. Welcoming the 2020 expo, which will take place from October 2021 to March 2022 , this area is anticipated to be the face of sustainable heritage culture from the legacy of Dubai's past as one of the land and sea trade centre points in the Middle East.

\section{References}

Al-Sayegh, F. (1998). Merchants' role in a changing society: the case of Dubai, 1900-90. Middle Eastern Studies, 34(1), 87-102.

Al Maktoum, S. M. B. R. (2001). Dubai: Regional hub for the new economy. Organisation for Economic Cooperation and Development. The OECD Observer, 224, 7.

Alawadi, K. (2017). Place attachment as a motivation for community preservation: The demise of an old, bustling, Dubai community. Urban Studies, 54(13), 2973-2997.

Alhosani, N., \& Zaidan, E. (2014). Shopping tourism and destination development: Dubai as a case study. The Arab World Geographer, 17(1), 66-81.

Assi, E. (2020). Role of Municipalities in the Urban Planning of Post-Oil Gulf Cities: The Case of Dubai, United Arab Emirates. WIT Transactions on Ecology and the Environment, 249, 3-9.

Belting, H. (2009). Contemporary art as global art: a critical estimate. na.

Boussaa, D. (2003). Dubai: The search for identity. People, Places and Sustainability, 51-60.

Boussaa, D. (2014). Cultural Heritage in the Gulf: Blight or blessing? A discussion of evidence from Dubai, Jeddah and Doha. Middle East-Topics 83 Arguments, 3, 55-70.

Academia Letters preprint.

(O)2021 by the author - Open Access - Distributed under CC BY 4.0 
Carter, R. J. (2015). Dubai: Past and Present Architecture in the Context of National Identity and Economic Development. Transformation of the Urban Character of Arab Cities since the Late Last Century, 14, 14.

Cuerrier, A., Turner, N. J., Gomes, T. C., Garibaldi, A., \& Downing, A. (2015). Cultural keystone places: conservation and restoration in cultural landscapes. Journal of Ethnobiology, 35(3), 427-448.

Dahliani, D. (2010). Local Wisdom Inbuilt Environment in Globalization Era. Local Wisdom Inbuilt Environmentinglobalization Era, 3(6).

Davidson, C. (2007). The emirates of Abu Dhabi and Dubai: Contrasting roles in the international system. Asian Affairs, 38(1), 33-48.

Elessawy, F. (2017). The boom: Population and urban growth of Dubai City. Horizons Hum. Soc. Sci, 2, 26-41.

Elsheshtawy, Y. (2004). Redrawing boundaries: Dubai, an emerging global city. In Planning Middle Eastern Cities (pp. 183-213). Routledge.

Ezzeddine, I., \& Kashwani, G. (2019). Public squares in UAE sustainable urbanism: Social interaction \& vibrant environment. Architecture Research, $9(2), 23-32$.

Farooq, H. A. Q., SERAPHİM, J., \& MEDHEKAR, A. (n.d.). Branding Heritage Tourism in Dubai: A Qualitative Study. Advances in Hospitality and Tourism Research (AHTR).

Gemenetzi, G. (n.d.). Dubai. From a 'tabula rasa'place to a world class city: The role of architecture and urban planning.

Govers, R. (2012). Brand Dubai and its competitors in the Middle East: An image and reputation analysis. Place Branding and Public Diplomacy, 8(1), $48-57$.

Henderson, J. C. (2006). Tourism in Dubai: Overcoming barriers to destination development. International Journal of Tourism Research, 8(2), 87-99.

Kaiser, J., \& AG, P. T. V. P. T. V. (2007). Dubai public transport bus

Academia Letters preprint.

(C2021 by the author - Open Access - Distributed under CC BY 4.0 
master plan: A new era of public transport services in the world's fastest developing city. Proceedings of 10th International Conference on Competition and Ownership in Land Passenger Transport.

Krane, J. (2009). Dubai: The story of the world's fastest city. Atlantic Books Ltd.

Lowry, G., \& McCann, E. (2011). Asia in the mix: Urban form and global mobilities-Hong Kong, Vancouver, Dubai. Worlding Cities: Asian Experiments and the Art of Being Global, 182-204.

Marzooqi, S. Al, Nuaimi, E. Al, \& Qirim, N. Al. (2017). E-governance (G2C) in the public sector: citizens acceptance to E-government systems-Dubai's case. Proceedings of the Second International Conference on Internet of Things, Data and Cloud Computing, 1-11.

Maspul, K. A. (2021). Revisiting The Sustainable Tourism in Indonesia. Academia Letters. https://doi.org/10.20935/AL1722

Mungmachon, M. R. (2012). Knowledge and local wisdom: Community treasure. International Journal of Humanities and Social Science, 2(13), 174181.

Noori, N., Hoppe, T., \& de Jong, M. (2020). Classifying pathways for smart city development: comparing design, governance and implementation in Amsterdam, Barcelona, Dubai, and Abu Dhabi. Sustainability, 12(10), 4030.

Rahman, M. H., Moonesar, I. A., Hossain, M. M., \& Islam, M. Z. (2018). Influence of organisational culture on knowledge transfer: $E$ vidence from the G overnment of D ubai. Journal of Public Affairs, 18(1), e1696.

Reisz, T. (2020). 9 All in All: Dubai World Trade Centre. In Showpiece City (pp. 265-317). Stanford University Press.

Ricca, S. (2018). Urban Heritage in the Arabian Peninsula, the Experiences of Jeddah and Dubai. Built Heritage, 2(3), 108-122.

Ryan, C., Ninov, I., \& Aziz, H. (2012). Ras Al Khor-Eco-tourism in con-

Academia Letters preprint.

(O)2021 by the author - Open Access - Distributed under CC BY 4.0 
structed wetlands: Post modernity in the modernity of the Dubai landscape. Tourism Management Perspectives, 4, 185-197.

Sharpley, R. (2008). Planning for tourism: The case of Dubai. Tourism and Hospitality Planning $\&$ Development, 5(1), 13-30.

Sindelar, M. (2016). Local, regional, global: An investigation of Art Dubai's transnational strategies. Arabian Humanities. Revue Internationale d'archéologie et de Sciences Sociales Sur La Péninsule Arabique/International Journal of Archaeology and Social Sciences in the Arabian Peninsula, $\%$.

Stephenson, M. L. (2014). Tourism, development and 'destination Dubai': cultural dilemmas and future challenges. Current Issues in Tourism, 17(8), 723-738.

Yas, H., Mardani, A., Albayati, Y. K., Lootah, S. E., \& Streimikiene, D. (2020). The Positive Role of the Tourism Industry for Dubai City in the United Arab Emirates. Contemporary Economics, 14(4), 601-617.

Zaidan, E. (2016). The impact of cultural distance on local residents perception of tourism development: The case of Dubai in UAE. Tourism: An International Interdisciplinary Journal, 64(1), 109-126.

Academia Letters preprint.

(O)2021 by the author - Open Access - Distributed under CC BY 4.0 